\title{
"BIO-POWER UP" ORGANIC FUEL ADDITIVE: GREEN CHEMISTRY FOR COST SAVINGS AND CLIMATE CHANGE MITIGATION
}

\author{
Dioscoro P. Marañon, Jr. \\ Paolo D. Petalver \\ West Negros University, Philippines \\ Joseph Edward O. Idemne \\ University of the Philippines - Visayas, Philippines \\ Larry Neil C. Abalajon \\ Lainie Mae L. Bala-an \\ Eric A. Malo-oy \\ Technological University of the Philippines - Visayas, Philippines
}

\begin{abstract}
The study aimed to determine the effect of using "Bio-Power Up" green, organic gasoline additive on the fuel consumption, power output and carbon dioxide emissions of engines in city driving, highway driving and stationary engine tests. The additive is produced from plants and vegetable extracts with a fuel enhancer containing methanol as one of its components. Experiments on city driving test were conducted on a Nissan 1990 model at the Vehicle Research and Testing Labiratory of the Department of Mechanical Engineering, University of the Philippines in Diliman, Quezon City. The 10-15 mode cycle Japanese model was used. Using t-test, there was no significant ( $p$-value $=0.207)$ decrease $(-0.60 \%)$ in the fuel consumption in $\mathrm{g} / \mathrm{km}$ but there was significant $(\mathrm{p}$-value $=0.008)$ increase $(5.00 \%)$ in the power output in $\mathrm{kW}$ when the additive was introduced. Truly, the $5.00 \%$ increase in power led to great fuel savings in highway driving. In the highway driving test of about $50 \mathrm{~km}$ drive back and forth, for the new Honda Wave motrocycle, a fuel savings of $7.23 \%$ was observed; for a Toyota Revo DLX, a fuel savings of $10.99 \%$ resulted; and for a Mitsubishi Lancer GLXi, a fuel savings of $171.80 \%$ was realized. The fuel savings depended on the condition of the engine. The fuel savings in highway driving would be at least P2.00 per liter of fuel consumed. A 4AFE EFI Toyota simulator engine was used in the fuel economy and carbon dioxide emissions tests on a stationary engine test. At $1101 \mathrm{rpm}$ and $2091 \mathrm{rpm}$, no substantial fuel savings was realized but at $4150 \mathrm{rpm}, 16.60 \%$ fuel savings and $0.20 \%$ increase in carbon dioxide emissions resulted with a net decrease of carbon dioxide emissions of about $2.41 \mathrm{ppm}$ by volume of gasoline used.
\end{abstract}

\section{KEYWORDS}

Gasoline additive; Organic; Green chemistry; Fuel savings; Carbon dioxide emissions

\section{INTRODUCTION}

https://doi.org/10.15626/Eco-Tech.2010.104 
The College of Engineering of West Negros University developed a green, organic fuel additive for gasoline called "Bio-Power Up" to lessen fuel consumption, corollarily, lessen the $\mathrm{CO}_{2}$ emissions to the atmosphere. The additive is composed of plant and vegetable extracts, and a fuel enhancer.

The objectives of the study were to determine the fuel savings, power increase and decrease in carbon dioxide emissions as a result of the use of additive in city driving, highway driving and stationary engine tests. Specifically, the study tested through acceptable standards the efficacy of the fuel additive in a reputable laboratory in terms of fuel economy, power output and carbon dioxide emissions using city driving test; and validated the results using the highway driving test and stationary engine test.

The price of gasoline has increased rapidly so there is a need to conserve fuel and find ways to save on fuel cost. Each year, the volume of vehicles increase and consequently raise the carbon dioxide emitted to the atmosphere coming from these vehicles. The study was conducted to enable the university to provide solutions to the high cost of increasing fuel prices, expand climate change mitigation initiatives and at the same time, and provide quality education to poor but deserving students.

The savings on fuel expense due to the use of the additive would not only lessen carbon dioxide emissions of vehicles to the atmosphere but also reduce oil imports, which would be boost our economy; these fuel savings will result to the reduction of transportation costs and the prices of commodities utilizing fuel as raw material.

\subsection{Climate Change Mitigation}

Tanton, Foss and Volkov [4] in their update on the Greenhouse Gas Mitigation Technologies by energy firms, other industry and the federal government enumerated the different ways to reduce greenhouse gas emissions. The technologies were divided into four categories: fuel substitution, nonhydrocarbon technologies, end use and enabling technologies. Fuel substitution technologies include liquefied natural gas (LNG), nuclear, and landfill gas. Nonhydrocarbon technologies include wind energy conversion, solar to electric, geothermal, biomass and biorefinery, biodiesel and ethanol production. End use technologies include stationary fuel cell applications, transportation applications (fuel cell, electric hybrid, flex fuel, high efficiency engines), and cogeneration. Enabling technologies include various consortia that are researching and developing a wide variety of technologies that were not delineated by specific technology. One is to improve energy efficiency and develop alternative energy sources like wind and solar. Another is carbon capture and storage (CCS), that is, capturing the carbon dioxide emitted by fossil fuel-fired power plants and store it underground.

The greenhouse gas mitigation technologies enumerated above are very expensive and need a large amount of investment to implement. What we need is a technology that is cheap but will have a significant effect to reducing carbon dioxide emissions to the atmosphere. Fuel enhancers

used as additives are very promising as these do not usually need engine modification and the fuel will just be mixed with the additive.

BioPerformance Fuel Additive was investigated by Wallace Environmental Laboratories, Inc. last January 2008 [5] for its effectiveness in reducing emissions and increasing fuel economy. 1,500 miles were accumulated prior to each test series to stabilize the vehicle prior to testing. A series of three EPA-75 Federal Test Procedure (FTPs) and three Highway Fuel Economy Tests (HFETs) for each vehicle were performed without the fuel additive. Each vehicle was subjected to another series of three EPA-75 FTPs and three HFETs after the fuel additive was introduced. The guidelines of 40CFR 86 was used for all testing in the study. On the average, 
the effect of the additive on fuel economy is $3.52 \%$ based on FTP and $2.785 \%$ based on HFET.

Extreme Lubricants Lab developed a tablet additive called Xrev Fuel Booster Treatment (FBT) last 1995 [3] which is based on its proprietary iron catalyst. The product was developed for international customers to have an economical and effective, yet environmentally friendly, fuel additive. Xrev FBT has an iron catalyst for octane boosting showing the same effectiveness that lead provides and at low concentrations without the environmental downside of lead. The controlled laboratory test was conducted for 950 hours and a 3.5\% increase in power was achieved using the additive. Fuel economy has also improved up to 8 to $12 \%$ using the additive.

Polar Molecular Corporation [1] developed the DurAlt Fuel Conditioner (DurAlt FC) which can control octane requirement increase (ORI) by inhibiting and reversing the build up of combustion chamber deposits (CCD). From 5 to 10 numbers increase in controls to only 2 or 3 numbers increase.

Environment Australia [2] in its paper on Proposed Management of Petrol Enhancing Additives in November 2000 evaluated the different octane enhancing additives in the areas of use, environmental and health issues, vehicle operability issue, effect on fuel specifications, and proposed management. Octane enhancers evaluated were Methanol, Ethanol, TertiaryButyl Alcohol (TBA), Iso Propyl Alcohol (IPA), n-propanol, Isobutanol, sec-Butanol, nButanol, Methyl Tertiary Butyl Ether (MTBE), Di-isopropropyl Ether, Ethyl Tertiary-Butyl Ether, Tertiary Amyl Methyl Ether, and Ethyl Tertiary Amyl Ether.

Although F2020 additive has been launched in the Philippine market, no publication has been made using it. Other additives from Korea are now entering the Philippine market but still no publication can be found about them. As of this time, no literature was found on additives which are of the same category with Bio-Power Up which is green, organic, renewable and sustainable gasoline additive.

\section{FUEL ENHANCER IN ADDITIVE}

The fuel enhancer added to plants and vegetable oil extracts contains methanol as one of its components. Green chemistry was considered so cold process mixing was used to produce the additive yielding very little cost to produce it. There is no limit on the capacity of production for the pilot processing plant at West Negros University (WNU), Philippines as it can easily be expanded.

The additive is renewable and sustainable, and does not contain any harmful ingredient to the engine and vehicle parts so it does not have a negative effect if adopted for use. Rubber parts were immersed on the additive and for more than a year, no negative effect was observed. Also, no engine modification was required in the use of the additive.

\section{VEHICLE AND ENGINE TESTS ON EFFECT OF ADDITIVE}

For all the tests, three (3) trials were conducted per parameter per test. Also, $1.0 \mathrm{ml}$ of additive per liter of unleaded gasoline was used and mixed thoroughly.

\subsection{City driving test using the Japanese 10-15 mode driving cycle for effect on fuel economy and power output}

For the city driving test, performance tests were conducted in the University of the Philippines - Diliman Mechanical Engineering Vehicle Research and Testing Laboratory 
(VRTL) using the AVL AN 40720 48" Chassis Dynamometer where the test vehicles were run on the Japanese 10-15 Mode driving cycle. Fuel consumption during the chassis dynamometer runs was measured with the AVL 735 Fuel Mass Flow Meter - AVL 753 Fuel Temperature Control units.

For the gasoline tests, a 1990 Nissan Sentra, 4-door sedan, newly overhauled, (Plate No. PNZ 390), with a 1600-cc naturally-aspirated carbureted gasoline engine was used as the test vehicle. The following pictures show the test vehicle mounted on the chassis dynamometer with attached instrumentation. No engine modification was required.

A Pre-Test inspection of the test vehicle is conducted to reasonably ascertain whether it is in good running condition. This includes general inspection of the tires, checking of tire pressures, checking for smooth and stable running of the engine. The test vehicle is then mounted on the dynamometer, secured, and instrumentation attached. The vehicle is then driven with the set test fuel using the Japanese 10-15 Mode driving cycle three times and the measurement results averaged.

A maximum power run after each drive cycle test is conducted to determine peak power. This consisted of driving the vehicle from idling condition and accelerating until wheel power reaches a maximum and begins to decrease with the gas pedal fully depressed and highest gear engaged. Commercially available unleaded gasoline fuel was used in the tests.

For the test using unleaded gasoline fuel, an initial (baseline) set of dynamometer runs was conducted without the Bio-Power Up fuel additive. After the baseline runs, the additive was mixed with unleaded gasoline fuel in the ratio $1.0 \mathrm{ml}$ Bio-Power Up to 1.0 liter unleaded gasoline. The test vehicle using fuel with the additive is then tested on the chassis dynamometer.

\subsection{Highway driving test on 50-km distance for effect on fuel economy}

For highway driving test, a new Honda Wave motorcycle, a Mitsubishi Lancer GLXi and a Toyota Revo DLX were used as vehicles to determine fuel savings. Their tanks were fully filled up with an unleaded gasoline from the $18^{\text {th }}$ St. Shell Station in Bacolod City, Philippines. From the station, we proceeded to Abuanan via Cansilyan, Murcia and vice versa. Distance travelled of

about $50 \mathrm{~km}$ was based on the odometer readings. Upon returning, the vehicles' tanks were again filled up and the amounts filled were recorded.

The same steps were followed with the gasoline mixed with additive using a ratio of $1.0 \mathrm{ml}$ additive to 1.0 liter gasoline.

\subsection{Stationary engine test for effect on fuel economy and carbon dioxide emissions}

A 4AFE Electronic Fuel Injector (EFI) Toyota gasoline engine simulator was used for the stationary test to verify decrease in fuel consumption and determine the decrease in carbon dioxide emissions to the atmosphere by the use of the additive. The equipment used for the emissions test were the MOT 251 Engine Analyzer with emission monitoring set up and the BEA Gasoline Exhaust Emission Analyzer.

For fuel economy tests, three (3) speeds were considered: $1101 \mathrm{rpm}, 2091 \mathrm{rpm}$ and $4150 \mathrm{rpm}$. For carbon dioxide emissions test, an idle speed and fast idle speed were considered. 


\section{RESULTS AND DISCUSSION}

The results of the city driving test showed that there is a $0.3 \mathrm{~g} / \mathrm{km}(0.41 \mathrm{ml} / \mathrm{km})$ or $-0.6 \%$ decrease $(58.8$ to $59.1 \mathrm{~g} / \mathrm{km})$ in fuel consumption and a $2.44 \mathrm{~kW}(3.27 \mathrm{hp})$ or $5 \%$ increase (48.86 to $51.30 \mathrm{~kW}$ ) in power when using the additive. These result was not significant on the increase in fuel economy ( $\mathrm{p}$-value $=0.207$ ) but was significant on the increase in power output ( $p$-value $=0.008$ ) using t-test. These small amounts of power increase could multiply in highway driving.

For highway driving test, the results showed that for new Honda Wave motorcycle, the increase in mileage or fuel economy is $7.232 \%$ (45.43 to $48.72 \mathrm{~km} / \mathrm{li})$. For the Revo DLX, the increase in mileage or fuel economy is $10.995 \%$ (15.32 to $17.00 \mathrm{~km} / \mathrm{li})$. For the Mitsubishi Lancer GLXi, the savings or increase in mileage is $171.80 \%(16.18$ to $43.98 \mathrm{~km} / \mathrm{li})$. It seemed that the age of the vehicle and/or the condition of the engine affected the effect of the additive on fuel economy.

For the stationary engine test, the first two speeds (1101 rpm and $2091 \mathrm{rpm})$ did not have a substantial effect on the fuel consumption but at the third speed $(4150 \mathrm{rpm})$, the fuel consumption decreased by $16.6 \%(90.00$ to $75.00 \mathrm{ml} / \mathrm{min})$ and the carbon dioxide emissions increased by $0.2 \%$ (14.71 to $14.74 \mathrm{ppm}$ by volume). There was a substantial net decrease in the carbon dioxide emissions of $2.41 \mathrm{ppm}$ by volume of gasoline used. The combustion became more efficient when using the additive at high speed.

Interested users of the additive were sought and were given the additive to be tested. Their testimonies are the following: a full tank on my motorcycle usually lasts for 4 days but now using the additive, it lasts for 5 days; a full tank on my motorcycle usually lasts for 3 days but now using the additive, it lasts for 6 days; P200 is the usual cost of my one day travel using my old Toyota Corolla but now using the additive, it lasts for 2 days; the usual cost of my travel from Bacolod City to Sipalay and back is P1,500 but using the additive, it reduced to only P800; and the usual consumption of my 'jeep' from La Carlota to Bacolod and vice versa is usually 8 liters but using the additive, it reduced to 6.8 liters $(15 \%)$. These testimonies verified the results of the city driving, highway driving and stationary engine tests conducted.

\section{CONCLUSIONS}

The use of the additive is not economically feasible in city driving as the decrease in fuel consumption was not significant and only the power increase was significant, however, it is very much economically feasible in highway driving as the savings per liter of gasoline is much higher than the cost of the additive. The decrease in fuel consumption in highway driving or in running the engine at high speed was substantial in the tests as verified also by the testimonies of users using the additive but there was a small increase in the carbon dioxide emissions due to a more efficient combustion inside the engine cylinder. The net decrease in carbon dioxide emissions was still substantial by using the additive in highway driving or in running the engine at high speeds. The additive can be easily promoted for use as it has no effect on engine and vehicle parts, and no engine modification is required.

\section{ACKNOWLEDGMENTS}

Special thanks is given to Dr. Suzette Lilian A. Agustin, West Negros University President for her full support to our research endeavors. Dr. Cleo Grace T. Hinaut, our VP for Academic Affairs, and Engr. Eduardo C. Leonor, former Dean of the College of Engineering, 
also encouraged us to produce more quality outputs. Mr. Vladimir Cebu, Engr. Fernando Emnace and Engr. Rey Ramos joined and witnessed our highway driving test.

\section{REFERENCES}

[1] Allsup, J. R., 1997. Advanced Fuel Additive Technology for Cost Effective Gasoline Lead Phaseout by Control of Octane Requirement Increase. Polar Molecular Corporation.

[2] Environment Australia, November 2000. Setting National Fuel Quality Standards: Proposed Management of Octane Enhancing Additives.

[3] Extreme Lubricants Lab, 1995. Xrev Fuel Booster Treatment: A Fuel Additive in Tablet Form.

[4] Tanton T., Foss M., Volkov D., June 2009. Key Investments in Greenhouse Gas Mitigation Technologies by Energy Firms, Other Industry and the Federal Government: An Update.

[5] Wallace Environmental Testing Laboratories, Inc., January 2008. BioPerformance Fuel Additive Study. 